\title{
Pollution and Environmental Degradation due to Covid-19 Pandemic: An Analysis under International Law
}

\author{
Amalia Zuhra SH., LLM., PhD \\ \{amalia.z@trisakti.ac.id\} \\ Universitas Trisakti, Jakarta, Indonesia
}

\begin{abstract}
The COVID-19 pandemic has changed the world in all aspects. A lot of casualties and huge economic losses are being experienced by all countries. Besides, the natural environment is also affected by this pandemic. The positive impact is the reduced air, water, and noise pollution due to the lockdown which minimizes human activities in all sectors and drastically lowers greenhouse gas emissions. On the other hand, environmental damage also occurs due to the pandemic, especially pollution caused by improperly managed plastics, masks, disinfectants, and other medical waste. This article discusses how international legal instruments have adapted to this pandemic and what steps should be taken by states as a form of global responsibility to deal with pollution and environmental damage due to the COVID-19 pandemic. This study is normative research and uses a descriptive-analytical method. The Basel Convention, an international agreement on controlling the transboundary movement of B3 waste and its disposal, is considered not sufficiently effective and comprehensive in preventing and overcoming pollution due to the COVID-19 pandemic. In addition, all states and non-state parties in the Basel Convention need to raise awareness, apply the precautionary principle, and enforce the law in dealing with pollution produced by the COVID-19 pandemic.
\end{abstract}

Keywords: COVID-19 Pandemic; International Law; Waste; Pollution

\section{Introduction}

The COVID-19 pandemic has caused great ramifications at every level of society. Unlike other natural disasters, the catastrophe of the COVID-19 pandemic, will not end in a short period of time and likely will be with us for a few years. The environment is one of the sectors that have been affected by the COVID-19 pandemic making activities such as waste management harder. Waste management in developing countries is usually not carried out in accordance with international standards. Therefore, the increasing amount of potentially infected waste that requires a more careful handling will raise some difficulties. From this pandemic, hopefully people can improve their waste management process and improve the system based on the lesson learned. 
The COVID-19 virus first spread at the end of 2019. This virus was first discovered in Wuhan, China. In a matter of months, it has spread widely throughout the world. Furthermore, this virus has become a big problem since it became a global pandemic. Not only health problems, but this pandemic also has an impact on other sectors, such as the economy, society, and environment. This article focuses on the impact of the COVID-19 pandemic on the natural environment. This pandemic has had a positive impact in which lockdown policies in many countries have been proven to reduce air, water, and noise pollution levels. In most countries, the government has issued a lockdown policy accompanied by social and physical distancing policies and "work from home" and "study from home" policies to control the spread of the COVID-19 virus. The reduction in community activities outside the home has led to a decrease in pollution levels which is indicated by qualitative and quantitative improvements in air conditions [1].

On the other hand, plastic pollution has been increased during the COVID-19 pandemic as single-use products has been favored by consumers due to safety reasons. This causes pollution due to the use of plastic and single-use items during this pandemic. One factor that has played an important role in protecting people during the COVID-19 pandemic are the usage of plastic products by the consumers. The increasing use of personal protective equipment known as "hazmat suits or personal protective equipment (PPE)" created major disruptions in supply chains and waste disposal systems, giving rise to growing concerns over the unprecedented increase in single-use plastics, including gloves, medical protective clothing, masks, hand sanitizer bottles, 'take away' food plastics, plastic wrappers, and medical test kits, such as antigen kits and PCR swabs. This happens since the COVID-19 pandemic began [2]. Eventually, a lot of single-use plastic waste (masks, gloves, PPE/hazmat, and hand sanitizer bottles) will arrive in the beach area so that it eventually can cause a surge of plastic that pollutes the sea shoreline and messes up the seabed.

In general, non-regulated dumping of biomedical waste has been considered a potential source of radioactive, toxic, and infectious. The medical waste consists of cytotoxic, chemical, pathological, pharmaceutical, sharps, radioactive, and general waste. The waste that has been generated like scalpels, gloves, syringes, face shield, and surgical masks are plastic wastes. The COVID-19 pandemic has created more biomedical waste in the form of plastic waste. As stated by WHO, an average of 0.2 and $0.5 \mathrm{~kg} /$ day of hazardous biomedical waste is produced by high- and low-income countries. Based on this situation, there are several identified main problems, namely as follows.

a. To what extent should international legal instruments adapt to the COVID-19 pandemic?

b. What efforts should be made by the countries as a form of an international obligation to avoid and handle pollution due to COVID-19?

This article presents the results of normative research with an analytical descriptive method. In this study, the researcher uses secondary data, namely data obtained through literature studies that have been collected, in the form of books, literature, laws, or other international agreements related to the object under study [3]. The secondary data in this study are divided into as follows.

a. Primary Legal Materials: binding legal materials consisting of basic norms or rules, general regulations, laws, jurisprudence, international agreements, and applicable legal materials [3]. Specifically, the primary legal materials used by the researcher are the 1989 Basel Convention on the Control of Transboundary Movement of Hazardous Waste, Technical Guidelines on the Environmentally Sound Management of Biomedical and Healthcare Wastes, and the 1972 Stockholm Declaration. 
b. Secondary Legal Materials: legal materials that explain primary legal materials [3]. These secondary legal materials are obtained by connecting the encountered problems with the laws and regulations, legal works in the form of books, articles, or scientific papers, and others related to International Environmental Law. In addition, these materials are accessed via the internet.

c. Tertiary Legal Materials: sources contain of definition and elaboration for primary and secondary legal materials, e.g., dictionaries, encyclopedias, cumulative indexes, digital books, digital journal websites, online dictionaries, and others [3].

\section{Discussion}

\subsection{Medical Waste as a Source of Pollution during the Covid-19 Pandemic}

WHO guidelines report (WHO, 2014; WHO, 2017) explains that waste generated by laboratories related to medical procedures, research centers, and healthcare facilities are categorized as healthcare waste. Home health care disposals for example treatment for kidney disease, treatment for diabetic disease, home use of insulin, or curative treatment) is also included [4]. Furthermore, health waste can be classified to eight groups, which consist of non-hazardous and hazardous components, namely (1) cytotoxic waste, (2) infectious waste, (3) sharps waste, (4) pathological waste, (5) chemical waste, (6) radioactive waste, (7) pharmaceutical waste, and (8) general non-hazardous waste [5].

Problems related to waste generated from health facilities, are an increase in the amount of infectious waste generation, disruption of recycling activities, disruption of health waste management services, insufficient capacity of trash bins, and improper health care waste management.

Meanwhile, the problems that arise from household/domestic waste are (1) an increase number of mixed disposal for example disposal that could generate infection due to the low level of separation at the base level), (2) an increase of the amount of plastic waste (due to the lockdown, WFH, and SFH policies), (3) the lack of inventory/estimated amount of generated household hazardous waste, (4) an increase in illegal dumping, open burning behavior, and littering, (5) postponing recycling, (6) the combining of disposal that could generate infection (tissues, hand gloves, and facemasks) with other waste which increases the chance of exposure to infection, (7) termination of formal and informal waste management services, (8) an increase in negative consequences (particularly in the informal sector) so that it must prioritize occupational health safety, health risks, lost business opportunities, and others, (9) inappropriate regional solid waste management services which is started at normal times (vulnerabilities in waste collection services, operations in the final disposal sites, and occupational health and safety), (10) an insufficiency of awareness about waste management, (11) reuse of discarded PPE, and (12) a shortage of daily PPE supply to waste pickers both official or unofficial officers (scavengers).

\subsection{International Law Regarding the Covid-19 Waste}

Sources of law in international law according to article 38 (1) of the Statute of the International Court of Justice are international treaties, international customs, general law principles accepted by civilized countries, court decisions, and expert opinions [6]. 
In terms of pollution caused by a pandemic, no specific international provisions are governing this matter. However, by considering the nature and type of pollutants that cause pollution during the COVID-19 pandemic (i.e., plastic, and medical waste), the international legal instrument that can be used is the 1989 Basel Convention on the Control of Transboundary Movement of Hazardous Waste. The discovery of large amounts of toxic waste in Africa and other third world countries in the 1980s causes this convention to be adopted in 1989. The negotiating countries at the time believed that the most effective way to protect human health and the natural environment from the harm generated by these wastes was to decrease the production of the wastes to the lowest possible quantity and/or lower than the hazardous potential level. Article 2 paragraph 1 of this convention states that waste is "Substances or objects which are disposed of or are intended to be disposed of or are required to be disposed of by the provisions of national law." The Basel Convention also explains what is meant by hazardous waste. It is waste which consists of 45 categories. In 18 categories, it is waste that can be seen from the source, such as hospital waste and polychlorinated biphenyl (PCB) plastic waste. Meanwhile, in 27 categories, it is waste that contains polluting elements, such as mercury, lead, asbestos, organic cyanide, halogenated organic solvents, and others. These wastes have 14 characteristic properties. Based on national regulations enforced in member countries of this convention, they are toxic and hazardous wastes. Another waste is waste which consists of 2 categories that require special attention, namely household waste, and household incinerator residue [7].

The Basel Convention issued the Basel Convention Technical Guidelines on the Environmentally Sound Management of Biomedical and Healthcare Wastes which regulates information and methods for using waste management for policymakers aimed at reducing hazards to humans and the environment. Biomedical waste management has steps that must be carried out properly and correctly, namely identification, collection, separation, storage, delivery, disposal, and processing. It also includes the process of disinfection, protection of personnel, and training of personnel [8]. Technical guidelines define "healthcare" as "medical activities, such as diagnosis, monitoring, treatment, prevention of disease, or alleviation of handicap in humans or animals, including related research, performed under the supervision of a medical practitioner or veterinary surgeon or another person authorized by virtue of his or her professional qualifications." Healthcare and Biomedical waste mentioned in these technical guidelines are liquid, solid, and gaseous wastes produced by healthcare facilities. Meanwhile, hazardous health care wastes are (1) infectious waste, 2) chemical waste, drugs, and cytotoxic drugs, (3) sharps waste, (4) radioactive waste, and (5) other hazardous waste.

All biomedical and healthcare that is known or have been clinically assessed by medical practitioners such as doctors or vet that has the potential to transmit infection to humans and animals are qualified as infectious healthcare waste. National circumstances, policies, and regulations can cause the interpretation of the definition of infectious healthcare waste to be varied. International organizations, such as WHO, have specific interpretations of the definition. The Basel Convention listed infectiousness as one of the dangerous characteristics. According to the technical guidelines, infectious healthcare waste is defined as follows. (1) It is disposal materials or equipment contaminated with blood and its derivatives, other objects, fluids, or feces from patients infected with dangerous infectious diseases. Another is contaminated waste from patients known to have blood-borne infections under hemodialysis (e.g., dialysis equipment such as tubes and filters, disposable bed sheets, linens, aprons, gloves, or laboratory coats contaminated with blood). (2) It is laboratory waste (cultures and stocks with biological agents that are feasible to be artificially cultivated to significantly 
increased amounts), including plates and devices used for transferring, injecting, and mixing cultures from infective agents and infected animals from laboratories [9].

Massive amount of unharmful materials and lesser number of harmful materials are included as biomedical and healthcare waste. Unharmful waste is like managed district waste and will not cause a health or other hazard than mismanaged district disposal. If hazardous wastes are not separated from other waste fractions (e.g., mixtures of biological and pathological wastes with sharps and body fluids), the entire waste should be treated as infectious waste. In this section, the potential dangers associated with exposure to biomedical and healthcare waste should be tackled properly [9]. The technical guidelines issued by the Basel Convention also explain who is at risk for the dangers of biomedical waste (Article 25 of [9]), what dangers arise from biomedical waste (Article 27-38 of [9]), waste classification (Article 40 of [9]), waste management guidelines, waste disposal management guidelines (Article 41-143 of [9]), waste management audits (Article 144-150 of [9]), and capacity building (Article 151-175 of [9]).

These technical guidelines, applied to biomedical waste generated by health facilities, classify waste based on the amount of waste, namely as follows (Article 39 of [9]).(1) Large: waste generated by clinics and university hospitals, maternity hospitals and clinics, and public hospitals. (2) Medium: waste generated by medical centers, outpatient clinics, funeral homes and autopsy places, farms and ponds, hospice, abortion clinics, medical laboratories, medical research centers, veterinary hospitals, blood banks and transfusion centers, and emergency departments. (3) Small: waste generated by general practitioner practices, nursing homes, medical consultation rooms, dentist practices, animal captivity, body tattooing places, acupuncture practices, veterinary practices, pharmacies, cosmetic piercing places, zoos, safari parks, and others.

As mentioned previously, in addition to written international legal rules like conventions and guidelines, international law, especially international environmental law, refers to the principles in international environmental law. Associated with the problem of medical waste due to the COVID-19 pandemic, the principle that can be implemented is mainly the principle of prevention. In addition, due to the hazardous nature of B3 waste and its risks to humans and the environment, B3 waste management must be carried out with a precautionary approach through the application of licensing instruments, starting from storage, collection, and transportation to its utilization and management. All its processes must be regulated properly.

\subsection{Handling Management in Indonesia}

The National Disaster Management Agency (Indonesian: Badan Nasional Penanggulangan Bencana (BNPB)) are the ones that handle the overall coordination of the COVID-19 issue in Indonesia. However, related to waste and waste management, Indonesia's Ministry of Environment and Forestry (Indonesian: Kementerian Lingkungan Hidup dan Kehutanan (KLHK)) stipulates several regulations, namely as follows.

a. Government Regulation No. 101/2014 concerning Management of Hazardous and Toxic Waste, which states that disposals come from handling Corona disease is categorized as hazardous waste,

b. Letter No. "S.167/MENLHK/PSLB3/PLB.3/3/3030" concerning "Handling of Health Workers in Health Facilities in an Emergency of COVID-19",

c. Circular Letter No. "SE.2/MENLHK/PSLB3/PLB.3/3/2020" concerning "Handling of Infectious Waste and Household Waste in the COVID-19 Situation", 
d. A specific letter from the Directorate General of Waste and Hazardous Waste Management of Indonesia's Ministry of Environment and Forestry to private transport, processing, and disposal companies related to the management of health waste in an emergency, including COVID-19 waste.

Even though there are many laws or regulation, these laws or regulation, in fact, is not necessarily applied broadly, adequately, or administered properly. An example for that is, common law may list hospital disposals as a part of toxic and dangerous materials, which is legally acceptable but ignores the reality that the handling of toxic and dangerous disposals from heath care units differentiates it greatly depending on the classification. These laws are also usually not enforced for a multitude of reasons leading to the informal waste sector to be practiced outside of the regulations.

Indonesia has a law addressing the management of solid waste, namely Indonesia's Law No.18/2008 concerning Waste Management. In addition, Indonesia also has environmental health standards for hospitals, regulated in "Indonesia's Minister of Health Regulation No. 1204/Menkes/SK/X/2004 concerning Hospital Environmental Health Requirements", which unfortunately is not applied practically. The ministerial regulation stipulates as follows.

a. Solid Waste Management Facility - Every heath care units must carry out disposal depletion starting from the base and have to handle and supervise the utilize of hazardous, toxic chemicals. In addition, every piece of equipment used in the management of medical waste in the collection, transportation, and disposal processes must be certified by the authorized party.

b. Liquid Waste Management Facilities - Liquid disposals should be piled up in boxes or drums that are suitable for type, amount, and managing and storage system of chemical and radiological waste. Hospitals must have respective wastewater treatment plants.

Indonesia's Minister of Health Regulation has explained in detail how to treat solid and liquid waste from community service facilities. If implemented properly, the possibility of contamination due to medical waste can be minimized. Another obstacle is national coverage which is not guaranteed even if there are national laws placed because of the lack of infrastructure in rural areas which is not a problem in urban areas.

The United Nations Environment Program (UNEP) stated that, the amount of medical waste produced in Indonesia is 290 tons per day. Medical waste is dominated by infectious waste. The high increase in waste is not matched by adequate management capacity so that it is not managed properly.

In addition, the infectious medical waste management process in Indonesia is also not handled properly and can cause air pollution. This is because the combustion method using an incinerator is still chosen by the community. Medical waste management capacity is also still inadequate and uneven, both in terms of quantity and distribution. The number of health care facilities that have licensed waste treatment facilities or incinerators currently only amounts to 110 hospitals out of a total of 2,889 hospitals that operate. In addition, only 5 of them have autoclaves. Meanwhile, of the 132 referral hospitals appointed by the government to treat COVID-19 patients, only 12 have licensed incinerators [10]. Frankly, all provinces should have medical waste processing equipment so that the handling of medical waste can be executed properly in all provinces with the concept of area-based medical waste management [11].

Another problem that occurs not only in Indonesia but also in many developing countries is how to enforce those policies and guidelines after all preparation is completed. Therefore, a national health care waste management policy is highly needed to encourage decision making process in government level and mobilize government actions and human resources for the 
successful implementation of the plan. Institutional, policy, and regulatory are the most important factor that should be thought about to be inserted in a health handling disposal policy.

Guidelines and International regulations for the safe management of healthcare waste are readily available and have been widely referenced and implemented by many countries. This serves as an excellent example for the management of healthcare waste during the Corona disease pandemic, especially for disposal comes from health facilities (both existing and newly built emergency health facilities). However, additional guidelines and regulations are still needed for health waste generated from non-health facilities, such as households and public places, especially due to the increase in potentially contaminated waste (such as masks, wipes, single-use clothing, and others). Furthermore, in this pandemic situation, good institutional management is very crucial. It is important to determine exact role, function, and responsibilities of those bodies in collecting disposals from hospitals and health care units and domestic disposals from private home and public areas. Other important factors are review and implementation of existing regulations and policies. It includes making of contingency plans, preparedness and Build Back Better for upgrading in health care unit's disposal management, and domestic disposals management. Because of that, having a review and evaluation of the existing law and system should be conducted to find out the lack of the system and implementation in each state. It is also needed in expanding the use of technologies at the maximum level [4].

\subsection{State Responsibility in Handling Pollution Due to Covid-19 Pandemic}

The state has the primary responsibility to protect its citizens living both within and outside of the jurisdiction territory of the concerned country. The concept of state responsibility in international law asserts that a state must be responsible for an act or omission that violates international obligation, whether born from an international agreement or from other sources of international law [1]. The forms of responsibility that can be carried out by a state are a statement of admitting mistakes, a statement of regret, an apology, and other ways that are considered appropriate (Article 37 of [12]). It can also be in the form of liability, namely related to legal accountability [13], including the provision of compensation or rehabilitation.

State responsibility started to take precedence after the United Nations Conference on Human and Environment was held in 1972 at Stockholm that produces the Stockholm Declaration. This document is the beginning of the further development of the principles of international environmental law, especially in article 21 stating that "State has, in accordance with the Charter of United Nations and the principles of international law, the sovereign right to exploit their own resources pursuant to their own environmental policies, and the responsibility to ensure that the activities within their jurisdiction or control do not cause damage to the environment of other States or of areas beyond the limits of national jurisdiction". This article becomes the basis for the principle of state obligations recognized by the International Court of Justice [14].

If associated with the principle of state responsibility above, it is expected that the problems related to infectious waste should not cause harm to the Indonesian people or beyond the limits of national jurisdiction so that it does not interfere with international interests. Therefore, the 'No-Harm' principle and the precautionary principle must become a strong foundation for a country in dealing with COVID-19. 
Apart from the state, there are other parties who are responsible for preventing and overcoming environmental damage and pollution caused by medical waste. In addition, there are those who question what the responsibility of business actors is who produce masks and medical equipment or other equipment, especially those made from single-use plastic. For producers, the imposed obligation is to comply with protocols and follow environmentally friendly product standards. In this case, the produced goods must be recycled properly (biodegradable). In addition, the component materials must be able to decompose in a short time, for example, "non-woven" materials. Besides, its process must be in line with the rules and standards of international institutions (i.e., WHO) and national institutions (i.e., Indonesia's Ministry of Health) [15]. Another solution is to be subject to Corporate Social Responsibility obligations. For example, in this case, financial assistance can be requested from them for handling hazardous waste, making depots for storing and processing waste masks, and managing transportation activities.

\section{Conclusion}

Currently, no international legal instrument specifically regulates waste generated from the COVID-19 pandemic. The hard law that is most likely to be applied is the Basel Convention which has technical guidance regarding the management of biomedical waste generated by health facilities. This legal instrument is considered sufficient to overcome the problem of medical waste created throughout the COVID-19 pandemic.

Pandemic is categorized as a national disaster. In other words, legally, everything is the responsibility of the state. All levels of government, from regional to central institutions, must work together. The government also should educate the public on how to treat infectious waste. In addition, the government must create a landfill for infectious waste and provide special officers who collect mask waste in a certain way. In general, the condition of medical waste management in Indonesia still faces challenges in the regulatory aspects, processing capacity, the role of local governments, coordination between institutions, human resources, infrastructure, licensing, the role of the private sector, and financing.

In Indonesia, medical waste management capacity is still inadequate and uneven, both in terms of quantity and distribution. All provinces should have medical waste processing equipment so that the handling of medical waste can be executed correctly that is in line with the instruction in Indonesia's Minister of Health Regulation No. 18/2020 concerning Regional-Based Medical Waste Management.

Indonesia, as one of the participants in the 1989 Basel Convention and a country that has ratified the convention by Presidential Decree No. 61/1993, must comply with the provisions of the convention. As for the waste problem due to the COVID-19 pandemic, it is expected that Indonesia can overcome it by applying the Basel Convention, especially technical guidelines which regulate in detail the technical implementation of biomedical waste management.

\section{References}

[1] A. S. Soedarso, Tanggung Jawab Negara atas Pelanggaran Berat HAM: Indonesia, Timor Leste dan lainnya. Jakarta: Raja Grasindo, 2005.

[2] N. U. Benson, D. E. Bassey, and T. Palanisami, "COVID pollution: impact of COVID19 pandemic on global plastic waste footprint," Heliyon, vol. 7, no. 2, p. e06343, 2021, 
doi: 10.1016/j.heliyon.2021.e06343.

[3] S. Soekanto, Pengantar Penelitian Ilmu Hukum. Depok: UI Press, 2010.

[4] "Waste Management during the COVID-19 Pandemic: from response to recovery," 2020. https://www.unep.org/resources/report/waste-management-during-covid-19pandemic-response-recovery.

[5] "Health-care Waste," 2018. https://www.who.int/news-room/fact-sheets/detail/healthcare-waste.

[6] M. N. Shaw, International Law, 3rd Editio. Cambridge University Press, 1991.

[7] D. Bilo, F. S. Istanto, and H. M. Triatmodjo, "Pertanggungjawaban Negara Terhadap Kerugian Dan Kerusakan Lingkungan Akibat Kbgiatan Ekspor Impor Limbah B3," Mns. dan Lingkung. PSLH UGM, vol. 12, no. 3, pp. 1-16, 2005, [Online]. Available: file://C:/Users/USER/Downloads/18639-37252-1-PB.pdf.

[8] "Waste management an essential public service in the fight to beat COVID-19," 2020, [Online].

Available: http://www.basel.int/Implementation/PublicAwareness/PressReleases/Wastemanageme ntandCOVID19/tabid/8376/Default.aspx.

[9] Secretariat of the Basel Convention, Basel Convention Technical Guidelines on the Environmentally Sound Management of Biomedical and Healthcare Waste. Chatelaine, 2003.

[10] T. Prasetiawan, "Permasalahan Limbah Medis Covid-19 Di Indonesia," Info Singk., vol. XII, no. 9, pp. 13-18, 2020.

[11] P. Mutiara and K. Suryatna, "Soroti Penanganan Limbah Medis yang Meningkat Selama Covid-19," 2021. https://www.kemenkopmk.go.id/soroti-penanganan-limbahmedis-yang-meningkat-selama-covid-19.

[12] J. Crawford, "The ILC's Articles on Responsibility of States for Internationally Wrongful Acts: A Retrospect," Am. J. Int. Law, vol. 96, no. 4, pp. 874-890, 2002, doi: $10.2307 / 3070683$.

[13] Sefriani, Hukum Internsional: Suatu Pengantar, Edisi Kedu. Jakarta: Raja Grafindo Persada, 2017.

[14] E. B. Weiss, The Evolution of Internastional Environment Law. Georgetown Law Faculty Publications and Other Works, 2011.

[15] K. Hidayat, "Ini dia Masker Medis Disposable Pertama berstandar SNI," 2021. www.kontan.co.id. 